\title{
VLIV ELEKTROMAGNETICKÉHO ZÁŘENÍ NA LIDSKÝ ORGANISMUS
}

\author{
RUDOLF Ladislav, CZ
}

\begin{abstract}
Resumé
Článek si klade za cíl seznámit veřejnost se základními otázkami účinků elektromagnetického pole na člověka a případných zdravotních rizik. Od začátku 20. století se používá mnoho elektrotechnických a elektronických zařízení, které od základů změnili životní styl. V posledních dvaceti letech došlo navíc $\mathrm{k}$ enormnímu nárůstu využívání bezdrátové komunikace jako nikdy v historii od zavedení rozhlasového vysílání v roce 1923 a televizního vysílání v roce 1953, kde na území Československa bylo několik vysílačů s vyšším výkonem 10 až 1000 kW, umístěných většinou mimo velká města. $\mathrm{V}$ současnosti používáme vysílače s výkony $10 \mathrm{~W}$ až $70 \mathrm{~W}$, v počtu kolem desetitisíc a další vysílače s nízkými výkony od $0,1 \mathrm{~W}$ do $1 \mathrm{~W}$, které jsou skoro v každé domácnosti. Většina těchto zdrojů záření je stále zapnutá a působí nepřetržitě 24 hodin na lidí v okolí. Jsme si vědomi, v jakém prostředí žijeme, když toto záření není vidět ani slyšet. Jaké jsou jeho účinky na lidský organizmus? Člověk je vystavený přirozeným zdrojům elektromagnetického pole (elektromagnetické pole země, kosmické záření, elektrostatické výboje $\mathrm{v}$ atmosfeřere, sluneční vítr a různé jiné) během celého svého života. S vědecko-technickým rozvojem přibyly umělé zdroje elektromagnetického záření, jako například rozhlasové a televizní vysílače, ale také základní stanice mobilních operátorů, mobilní a bezdrátová komunikace, detekční zařízení na letištích, nebo bezpečnostní systémy $\mathrm{v}$ obchodech. Umělé zdroje elektromagnetického pole mohou vyvolávat tepelné účinky na živé organismy a také biologické. Součástí př́ispěvku je průzkumné šetření k dané problematice.
\end{abstract}

Klíčová slova: záření, bezdrátová komunikace, elektromagnetické pole, biologické účinky, mobilní operátoři.

\section{EFFECTS OF ELECTROMAGNETIC RADIATION ON THE HUMAN BODY}

\begin{abstract}
The article aims to acquaint the public with the basic issues of the effects of the electromagnetic field on humans and their potential health risks. Since the beginning of the 20th century, many electrical and electronic devices have been used that have fundamentally changed their lifestyle. In addition, there has been an enormous increase in the use of wireless communication in the last twenty years than ever before - since the introduction of radio broadcasting in 1923 and television broadcasting in 1953, where there were several transmitters with a higher output of 10 to $1000 \mathrm{~kW}$ in Czechoslovakia, mostly located outside large cities. We currently use transmitters with outputs of $10 \mathrm{~W}$ to $70 \mathrm{~W}$, in the number of about tens of thousands, and other transmitters with low outputs from $0.1 \mathrm{~W}$ to $1 \mathrm{~W}$, which are in almost every household. Most of these radiation sources are still on and affect people around for 24 hours a day. Are we aware of what environment we live in when this radiation cannot be seen or heard? What are its effects on the human body? Man is exposed to natural sources of electromagnetic fields (the earth's electromagnetic field, cosmic rays, electrostatic discharges in the atmosphere, the solar wind and various others) throughout his life. With the scientific and technical development, artificial sources of electromagnetic radiation have been added, such as radio and
\end{abstract}


television transmitters, but also base stations for mobile operators, mobile and wireless communication, detection devices at airports, or security systems in shops. Artificial sources of electromagnetic fields can cause thermal and non-thermal biological effects on living organisms. Part of the paper is an exploratory survey on the issue. Survey aimed at that issue is part of the contribution.

Key words: radiation, wireless communication, electromagnetic field, biological effects, mobile operators.

\section{Úvod}

Člověk je vystavený přirozeným zdrojům elektromagnetického pole (elektromagnetické pole Země, kosmické záření, elektrostatické výboje v atmosfére, sluneční vítr a různé jiné) během celého svého života. S vědecko-technickým rozvojem přibyly umělé zdroje elektromagnetického záření, příkladem jsou rozhlasové a televizní vysílače. Mezi ně také patří základní stanice mobilních operátorů, mobilní a bezdrátová komunikace, detekční zařízení na letištích, nebo bezpečnostní systémy v obchodech. Umělé zdroje elektromagnetického pole mohou vyvolávat tepelné a biologické účinky na živé organizmy. Hlavním cílem článku je vysvětlení problematiky elektromagnetického záření, které $\mathrm{v}$ dnešní době je nezbytným prostředkem pro správnou funkci moderních zařízení. Jedná se například o užívání mobilního telefonu a jiných zařízení, které pracují v bezdrátovém režimu a jsou lidstvem denně použivány. Dílčím cílem v článku je předvýzkum omezeného vzorku respondentů a zpracování jeho výsledků a následné stanovení závěrů.

\section{Elektromagnetické pole}

Elektromagnetické pole jako záření je charakterizované vlnovou délkou $\lambda$, frekvencí $f$ a intenzitou magnetického pole $H$ a elektrického pole $E$. Má vlnový korpuskulární charakter, chová se tedy jako vlnění i jako hmotné částice. Vztah mezi frekvencí a vlnovou délkou určuje vztah, ze kterého vyplývá, že čím je vyšší frekvence $f$ pole, tím je menší jeho vlnová délka $\lambda$, přičemž $c$ je rychlost šiřrení světla.

$$
f=\frac{c}{\lambda}\left(H z ; m \cdot s^{-1} ; m\right)
$$

Pole jako záření má elektrické a magnetické složky a vektory těchto složek jsou k sobě kolmé. Na obrázku 1 je znázorněná vlnová délka pole, jeho magnetické a elektrické složky. Celé spektrum elektromagnetického pole možno vyjádřit pomocí vlnové délky nebo pomocí frekvence a rozděluje se na neionizující a ionizující záření.

Ionizující záření má okamžité destruktivní účinky na lidský organismus, nachází se na nižších vlnových délkách, než je viditelné světlo a ultrafialové záření. Jde o rentgenové záření a záření gama, jeho velikost vlny je menší $10 \mathrm{~nm}$. Délka vlny je porovnatelná s mikroskopickými částicemi hmoty a nabourává jejich chemické vazby. Při těchto druzích záření se nepochybuje o jejich zhoubných účincích na lidský organismus.

Každé zapnuté elektrické zařízení spotřebovávající elektrickou energii vyzařuje elektromagnetické pole, je zdrojem neionizujícího záření. Vyzařování se liší intenzitou a frekvencí podle konstrukce daného zařízení. Jsou to např́íklad zařízení pro průmyslové a privátní využití, elektrické motory, rozvody elektrické energie, rádiové a televizní vysílání, dále mobilní telefony, optické lasery a opalovací lampy v soláriích. Neionizujíce záření zahrnuje elektromagnetické pole s frekvencí od 0 do $300 \mathrm{GHz}$ a patří sem i infračervené záření, viditelné světlo a ultrafialové záření. Neionizující záření nedokáže z energetického hlediska vyvolat ionizující biologické struktury. 


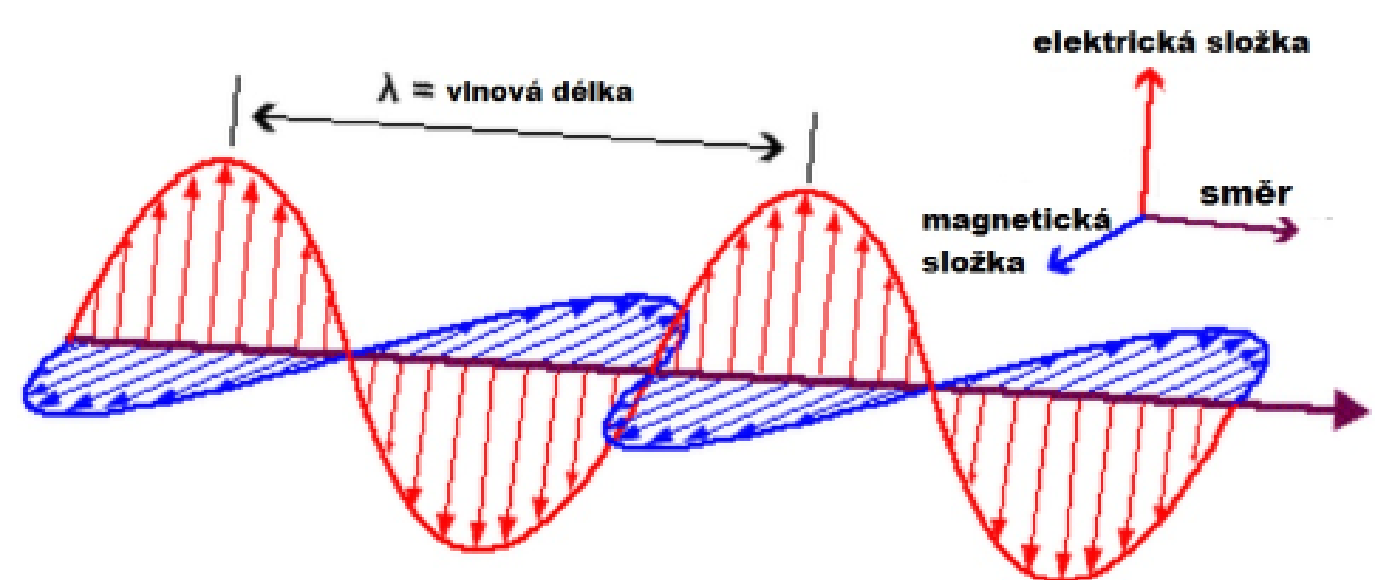

Obrázek 1 - Elektromagnetické pole, jeho složky a vlnová délka (https://elektro.tzbinfo.cz/docu/clanky/0133/013319o4.jpg)

\section{Vliv elektromagnetického pole na lidský organismus}

Známe dva druhy vlivu biologických účinků elektromagnetických vln, jedná se o tepelné a netepelné. Netepelné účinky není je možné oddělit od tepelných, které převažují při velkých intenzitách a závisí na odevzdané energii. Tepelné účinky výrazně rostou se stoupající frekvencí a jsou nejzávažnější v pásmu mikrovln. Netepelné efekty jsou určené převážně okamžitou amplitudou vysokofrekvenčního záření. Jejich význam stoupá při opakovaném ozařování poměrně malými intenzitami, zvlášt' potom při ozařování impulzními poli, při nich je celkový odevzdaný výkon poměrně malý, ale okamžitá amplituda značně velká. Za této situace začínají převládat netepelné efekty nad tepelnými. Při tepelných účincích je jejich závislost daná tím, že elektrické vlastnosti jednotlivých tkaniv se mění s frekvencí záření. Frekvence pro maximální ohřev lidského těla leží v pásmu velmi krátkých a centimetrových vln. Všeobecně možno říct, že s rostoucí frekvencí stoupá ohřev tkaniva.

Daleko významnějším jako frekvenční závislost je vliv různého charakteru vyzařovaného signálu, který může být bud' nemodulovaný, potom je pole nepřetržité s konstantní amplitudou, nebo modulovaný. Hraničním př́padem amplitudového modulovaného signálu je impulzní modulace. V praxi je dokázané, že větší biologická aktivita je způsobená netepelnými účinky elektromagnetického pole $\mathrm{v}$ impulzním režimu. Tento poznatek je v současnosti využívaný v medicínské oblasti jako je např́iklad vysokofrekvenční impulzní elektro magnetoterapie, kde účinky vysokofrekvenčních polí jsou řízeně využívané na léčebné účinky při přesně stanovených dávkách a době ozařování.

Působení na organismus se děje ve dvou rovinách:

- ohřev vlivem absorbovaného vysokofrekvenčního výkonu,

- působení elektrických proudů indukovaných v těle vlivem elektrického a magnetického pole.

Vlivem absorbovaného vysokofrekvenčního výkonu dochází k ohřevu organizmu. Při absorbovaném výkone $4 \mathrm{~W}$ na kilogram tkaniva dochází k ohřevu o $1{ }^{\circ} \mathrm{C}$. Organizace zabývající se ochranou před neionizujícím zářením stanovili maximální přípustný absorbovaný výkon elektromagnetického záření na celé tělo velikosti $0,4 \mathrm{~W} / \mathrm{kg}$, tedy 10 násobně nižší.

Pro obyvatelstvo je mezní hodnota $0,08 \mathrm{~W} / \mathrm{kg}$, tedy 50 násobně nižší jako je hodnota, při které dojde k ohřevu těla $o 1^{\circ} \mathrm{C}$. V praktických situacích je téměř vyloučené, aby se člověk setkal s takou vysokou expozicí. Pokud nějaký elektromagnetický zdroj záření přesahuje uvedené limity, je chráněný za branami, čím znemožňuje přístup do ohrožené zóny. 
Nízkofrekvenční elektrické a magnetické pole, s kterými se mohou setkat obyvatelé, je však na tak nízké úrovni, že proudy, které tyto pole indukují, jsou v podstatě o několik řádů nižší než je prahová hodnota. Jde $\mathrm{v}$ podstatě o proudy indukované $\mathrm{v}$ těle magnetickým polom, které vzniká v okolí každého vodiče, přes který protéká elektrický proud. Toto magnetické pole však rychle klesá se vzrůstající vzdáleností od vodiče.

Umělé zdroje záření jsou však hluboko pod limity, které stanovují příslušné národní normy nebo směrnice. Někteří lidé mohou být mimořádně citliví na působení i velmi slabých magnetických nebo elektrických polí. Projevují se u nich bolesti hlavy a očí, zvracení, točení hlavy, porucha spánku.

Proto se odporučuje:

- $\quad$ z pokoje odstranit všechny elektrospotřebiče (televizní přijímač, počítač), resp. je umístit co nejdále od hlavy,

- $\quad$ aspoň po dobu spánku vypínat spotřebiče ze zásuvky a nenechávat je v pohotovostním režimu,

- telefonovat co nejméně a co nejkratší dobu,

- při posílání SMS držet mobil co nejdále od těla,

- nedávat si mobil do kapes v kalhotách,

- při používaní mobilu preferovat hands-free sadu.

\section{Mobilní telefon a zdraví}

Mobilní telefony pracují na vlnové délce zhruba $30 \mathrm{~cm}$. Kvantum této energie je menší než jedna milióntina energie potřebné pro ionizaci. Průmyslové elektrické vedení produkují elektromagnetické záření o vlnové délce 6000 km s kvantem energie miliónkrát nižším.

O mobilních telefonech, z důvodu velkého množství informací na internetu a jiných médiích za posledních 5 až 7 roků, jsou často tyto informace rozporuplné. Co se možno dočíst na internetových fórech? Např́iklad, záření z mobilního telefonu poškozuje zdraví, způsobuje poškození buňkových membrán, způsobují zvýšené riziko vzniku mozkových nádorů a podobně. Jednou se vyskytne informace, že mobilní telefony škodí, někdy, že nejsou škodlivé. Cílem je objasnit v čem je problém, proč odpověd' na otázku, či je škodlivý nebo nevíme hned a jakým způsobem by mohly mobily škodit nebo ne.

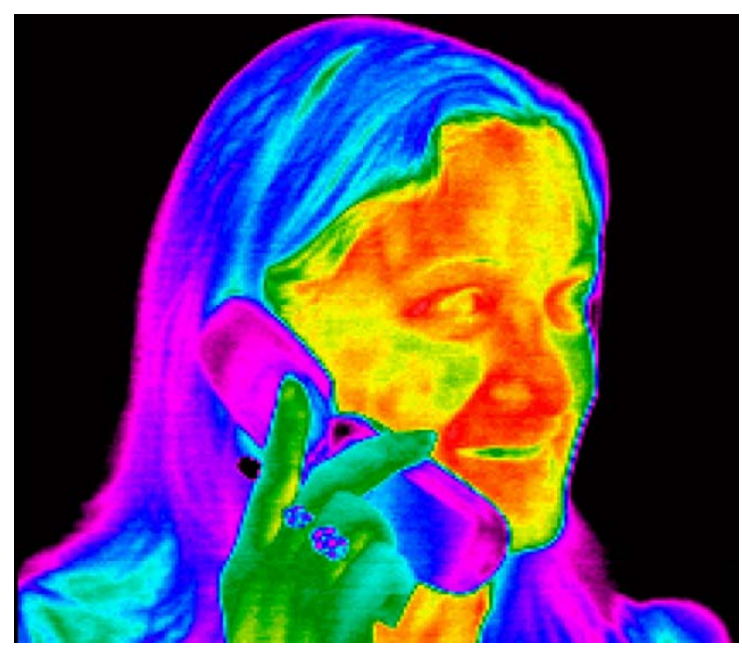

Obrázek 2 - Přehřivání mozku zářením mobilního telefonu

(https://servis.idnes.cz/fbimg.aspx?foto=JM5e84d8_profimedia_0102985021.jpg\&c=A151009_155 202_mob_tech_oma) 
Když se podíváme na škodlivost mobilních telefonů na internetu, tak najdeme informace proti mobilům. V mozku jim mohou vzniknout nádory, které jim způsobují mobily (obr. 2). Toto jsou informace, které nejvíc rezonují v médiích, že používání mobilních telefonů pravděpodobně zvyšuje riziko vzniku nádorových onemocnění mozku. Jaké hlavní účinky má elektromagnetické záření? Z obrázku 3 je zřejmé, že mobilní telefon vyzařuje neionizující záření.

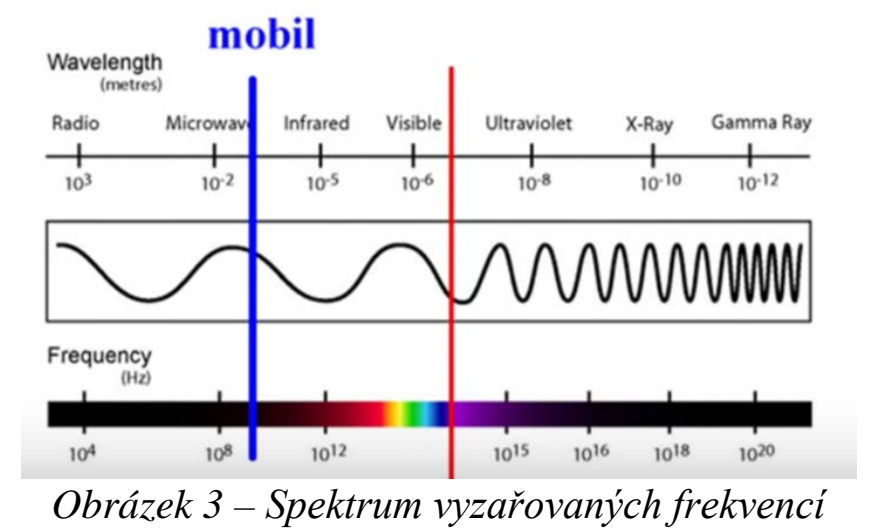

(https://lh3.googleusercontent.com/proxy/HRgqUnJPMiY7GDZQTCrpRTDxelnoz9LyZhSmJQbotLD DzVV21dQ3NjpwJLuNkVbqttm0x5ziq3XI62IcRiIxr4tDelDHbLyo9QHwokpBZezQOuvAO3aAvdGrqZeZp4)

Co si třeba ujasnit, když se chceme bavit o účincích elektromagnetického záření, elektromagnetické záření mobilních telefonů podle frekvence se dělí na dvě hlavní skupiny. Jedna je ta, která dokáže ionizovat a druhá ta, která nedokáže ionizovat. V podstatě hranice se nachází v oblasti ultrafialového záření. Záření, které má frekvenci vyšší jako ultrafialové záření má takovou energii, která dokáže vyvolat chemickou reakci. Záření, které má nižší frekvenci nedokáže chemické reakce vyvolat. Takže když se necháte ozařovat rentgenovým ultrafialovým nebo jiným zářením se může při dopadu na vaše buňky k chemickým reakcím poškodit DNA. Takové záření má prokazatelně rakovinotvorné účinky. Mobilní telefon se nachází asi o tři rády pod velikostí energie, která dokáže vyvolat chemickou reakci, nebot' záření mobilních telefonů se jmenuje záření, které nemá energii na vyvolání chemické reakce. To je poprvé, že nemůžeme hledat účinek ozáření, které vyvolá v nás podobné účinky jako ultrafialové záření. Tato energie je tisíc krát menší jako energie potřebná na vyvolaní jakékoliv chemické reakce. Co může způsobit elektromagnetická vlna, když se nacházíme v elektrickém i magnetickém poli, které může v lidském organizmu vyvolat vznik elektrických proudů. Elektrické pole může vyvolat elektrický proud, nebo proměnné magnetické pole může přes Faradayův indukční zákon vyvolat proudy. Víme, že účinkem elektrického proudu na organizmus může být elektrolýza, poškozením buňkových membrán nebo ohřev (popálení). Při elektrolýze a poškozeních buněčných stěn potřebujeme, aby ionty přecházeli určitou dráhu k elektrodám. Následně aby začala elektrolýza a aby př̌šli ionty buněčnou stěnou, pokud má dojít k poškození buněk. Problém v dobrém smyslu slova je v tom, že frekvence mikrovln je velmi vysoká. Frekvence mobilních telefonů je okolo $2,5 \mathrm{GHz}$, nebot' perioda je cca $10^{9} \mathrm{~s}$ a za tento čas ionty neprojdou, to si můžeme demonstrovat na výpočtu.

Jak vypadá mikrovlnný proud v lidském těle? Předpokládejme, že lidské tělo se skládá cca z 0,5 \% roztoku chloridu sodného $(\mathrm{NaCl})$, to je zhruba fyziologický roztok, metr kubický obsahuje $10^{26}$ iontů x $1,6.19^{-19} \mathrm{C}=1,6.10^{7} \mathrm{C} / \mathrm{m}^{3}$. Podstatná věc je, předpokládejme že přes lidské tělo pustíme proud $1 \mathrm{~A} / \mathrm{mm}^{2}$, to je už dost velký proud, t. j., že každým mm² těla pustíme proud $1 \mathrm{~A}$, co je velká hodnota, potom za půl periodu signálu $2 \mathrm{GHz}$ projde myšlenou plochou náboj $10^{6} \mathrm{~A} / \mathrm{m}^{2} \times 10^{-9} \mathrm{~s}=10^{-3} \mathrm{C} / \mathrm{m}^{2}$. Toto odpovídá pohybu iontů za půl periodu o $\left(10^{-3} \mathrm{C} / \mathrm{m}^{2}\right) /\left(1,6.10^{7} \mathrm{C} / \mathrm{m}^{3}\right)=6.10^{-11} \mathrm{~m}$. Máte představu, zda je to hodně nebo málo, máte představu o rozměrech atomů, kolik to asi je? Jaký je typický rozměr 
atomu? Typický rozměr atomu je $10^{-10} \mathrm{~m}$, to je o něco méně než velikost atomu. Mikrovlnný proud, který teče přes lidské tělo není tak velký proud, který si přestavujete, že ve vodičích teče jedním směrem, to je ve skutečnosti jen takové jemné chvění v rámci rozměru atomů. Takže elektrolýza nepřipadá $\mathrm{v}$ úvahu, tam se potřebujete přesunout $\mathrm{z}$ jednej elektrody na druhou. Buněčné stěny nepřipadají do úvahy, tam se potřebujete dostat na buněčné rozměry, zlomky mikrometru. Pak zůstává, je už jen ohřívání. Víme, že účinek mikrovln je relativně velmi malý můžeme prezentovat pokusem se zdrojem záření na úrovni $1 \mathrm{MHz}$, což je 1000 krát menší frekvence jak je frekvence mobilního telefonu, nebot' ionty projdou 1000 krát větší vzdálenost přes lidské tělo, t. j. $10^{-8} \mathrm{~m}$ což je stále dost málo a výkon mobilního telefonu je typicky cca. 2 až $3 \mathrm{~W}$, a náš zdroj záŕení má $20 \mathrm{~W}$, to je 10 krát více. Náš generátor je schopný vyvolat proudy o čtyři řády vyšší než mobilní telefon. Tímto experimentem (jeden konec lineární zářivky přiložíme na generátor a druhý držíme v ruce) můžeme rozsvítit lineární zářivku. Elektrický proud teče přes lidské tělo, ve skutečnosti se atomy chvějí na jednom místě, člověk nic necítí, protože to nemůže vyvolat žádnou reakci, ani přechod přes membránu buňky nervovými signály, nemá to žádný účinek ani fyziologický ani chemický, funguje to úplně bez problémů. Proud tak vysoké frekvence, který protéká lidským tělem nic nezpůsobí, ale způsobuje ohřev. Člověka se při pokusu neohřrivá, protože nechává protékat proud velkou plochou cca $1 \mathrm{~cm}^{2}$, nebot' ohřev se rozloží na velkou plochu. Problém by nastal v tom př́ípadě, kdyby energie byla soustředěna na malé ploše. Toto budeme demonstrovat pomocí hrotu, tím můžeme dostat výboj na velmi malou plochu, to odpovídá zlomku milimetru a tam tepelný fyziologický účinek může být mnohokrát větší a teplota může být vyšší, to si demonstrujeme zapálením papíru. Když se dotýkáme velkou plochou tak nic necítíme, ale když se dotkneme například. jen jedním prstem, tak nás to popálí, protože proud soustředíme do velmi malé plochy. Nic necítíme ani popálení, protože to okamžitě spálí všechny nervové zakončení.

\section{Dotazníkové šetření}

Na základě výsledků předvýzkumu v dotazníkovém šetření, došlo k zodpovězení vybraných otázek ohledně působení elektromagnetického záření na lidský organismus vlivem užívání mobilního telefonu nebo jiných spotřebičů a zařízení produkující záření. Výsledky jsou zpracovány do tabulky, kde počet odpovědí respondentů je uveden v tabulce 1 a tím i otázky, které z dotazníku plynou. Jednoznačně se ukázalo, že všichni respondenti užívají mobilní telefon, který používají v krátkém časovém úseku. Dále, že většina má mobilní telefon stále zapnutý vedle sebe v čase spánku. Důležitým údajem bylo zjištění, že většina respondentů užívá mobilní telefon k vyhledávání informací na internetu a čtení emailů. Telefon vlastní více jak deset let. Údajem, zda respondenti ví o vedlejším účinku elektromagnetického pole u mobilních telefonů a jiných spotřebičů, produkující záření, odpověděla ve dvou verzích odpovědí většina respondentů.

Problematika působení elektromagnetického pole je stále aktuální a díky moderním zařízením a komunikaci bude stále oblastí, které je třeba věnovat pozornost. Ve světě i u nás stále probíhají výzkumy, které objasňují oblast vlivu záření na organismus člověka. 
Tabulka 1 - Výsledky dotaznikového šetření

\begin{tabular}{|c|c|}
\hline 1. Označte, kolik mobilních telefonů použiváte? & počet odpovědi \\
\hline nepoužívám mobilní telefon & 0 \\
\hline používám jeden mobilní telefon & 29 \\
\hline dva mobilní telefony & 0 \\
\hline tři mobilní telefony & 0 \\
\hline čtyři a více mobilních telefonů & 0 \\
\hline $\begin{array}{l}\text { 2. Označte, kolik hodin průmérně protelefonujete } \\
\text { z mobilního telefonu za jeden den? }\end{array}$ & počet odpovědí \\
\hline $\begin{array}{l}\text { mobilní telefon používám minimálně, jen několik } \\
\text { minut měsíčně }\end{array}$ & 0 \\
\hline 2 až 5 minut denně & 12 \\
\hline 5 až 10 minut denně & 5 \\
\hline 10 až 30 minut denně & 8 \\
\hline více jak 30 minut denně & 4 \\
\hline $\begin{array}{l}\text { 3. Máte mobilní telefon v čase spánku zapnutý } \\
\text { v blízkosti postele? }\end{array}$ & počet odpovědí \\
\hline $\begin{array}{l}\text { mám ho zapnutý vedle mne na posteli v čase } \\
\text { spánku }\end{array}$ & 18 \\
\hline mám, ale je vypnutý & 6 \\
\hline ne, nemám ho vedle sebe v čase spánku & 5 \\
\hline $\begin{array}{l}\text { 4. Uvědomujete si potenciálně škodlivých účinků } \\
\text { elektromagnetického pole u elektrických } \\
\text { a elektronických zařízení, které ve vašem okoli } \\
\text { běžně používáte? }\end{array}$ & počet odpovědí \\
\hline Ano, uvědomuji si to velmi dobře & 13 \\
\hline $\begin{array}{l}\text { něco jsem už o tom slyšel(a), ale víc jsem se o to } \\
\text { nezajímal(a) }\end{array}$ & 16 \\
\hline ne, slyším o tom poprvé & 0 \\
\hline $\begin{array}{l}\text { 5. Označte svioj věk, od kterého použiváte mobilní } \\
\text { telefon }\end{array}$ & počet odpovědí \\
\hline 5 roků & 0 \\
\hline 6 až 10 roků & 12 \\
\hline 11 až 15 roků & 17 \\
\hline 16 až 20 roků & 0 \\
\hline $\begin{array}{l}\text { 6. Označte, kolik hodin denně se věnujete } \\
\text { internetu }\end{array}$ & počet odpovědí \\
\hline nepoužívám internet & 0 \\
\hline 1 až 2 hodiny denně & 11 \\
\hline 3 až 5 hodin denně & 6 \\
\hline 5 až 10 hodin denně & 12 \\
\hline víc jak 10 hodin denně & 0 \\
\hline 7. K jakému účelu použiváte internet? & počet odpovědí \\
\hline e-mail & 14 \\
\hline vyhledávání informací & 26 \\
\hline práce se softvérem & 4 \\
\hline jiné (soc. sítě, e-knihy, školení, filmy, a další) & 14 \\
\hline
\end{tabular}




\section{Závěr}

V závěru článku jsou zpracovány výsledky, které z pozice významného vzorku respondentů ukazují jasné oblasti lidské činnosti, které vedou k působení elektromagnetického pole na lidský organismus. Článek se zaměruje výhradně na činnosti a zařízení, produkující elektromagnetické záření, nikoliv na fyzikální vlivy. Výsledky ukázaly, že hlavním vlivem záření na lidský organismus je u vybraných respondentů délka denního užívání mobilního telefonu a zařízeních produkující toto záření. Samotné výsledky jsou doloženy v tabulce 1.

Zkoumání vlivu elektromagnetického záření na lidský organismus je provedeno pomocí vybraných otázek dotazníkového šetření na vzorku studentů. Je zde na respondenty kladeno sedm otázek, které například řeší otázku používání počtu mobilních telefonů, času volání během dne, uložení mobilního telefonu během spánku nebo kjakým aplikacím ho respondent používá a zařízení užívající elektromagnetické pole. Výsledky předvýzkumu ukázaly, že většina respondentů používá jeden mobilní telefon. Konkrétní další odpovědi na otázky dotazníku jsou patrné z tabulky 1, kde jsou zaznamenány počty odpovědí respondentů. V kapitole dotazníkového šetření jsou uvedeny plynoucí závěry předvýzkumu omezeného vzorku respondentů.

\section{Literatura}

CHRÁSKA, Miroslav, (2016). Metody pedagogického výzkumu: základy kvantitativního výzkumu. 2., aktualiz. vyd. Praha: Grada. Pedagogika. ISBN 978-80-247-5326-3.

COCHEROVÁ, Elena a V. ŠTOFANÍK, (2010). Numerické metódy riešenia bioelektromagnetických polí: Numerical methods of solution of electromagnetic fields. Bratislava: Slovenská technická univerzita. ISBN 978-80-227-3272-7.

MAYER, Daniel, (2012). Aplikovaný elektromagnetizmus: úvod do makroskopické teorie elektromagnetického pole pro elektrotechnické inženýry. 2. vyd. České Budějovice: Kopp. ISBN 97880-7232-436-1.

VRBA, Jan, (2003). Lékařské aplikace mikrovlnné techniky. Praha: Vydavatelství ČVUT. ISBN 8001-02705-8.

INSKIP P.D., TARONE R.E., HATCH E.E., WILCOSKI T.C. SHAPIRO W.R. SELKER R.G., (2001). Cellular-telephone use and brain tumors., (2001) New England Journal of Medicine, 344 (2), pp. 79-86.

MUSCAT J.E., MALKIN M.G., THOMPSON S., SHORE R.E., STELLMAN S.D., McREE D., (2000). Handheld cellular telephone use and risk of brain cancer, Journal of the American Medical, Association, 284 (23), pp. 3001-3007.

SATO Y., AKIBA S., KUBO O., YAMAGUCHI N., (2011). A case-case study of mobile phone use and acoustic neuroma risk in Japan, Bioelectromagnetics, 32 (2), pp. 85-93.

\section{Kontaktní adresa:}

Ladislav Rudolf, doc. Ing. Ph.D., Katedra technické a pracovní výchovy, Pedagogická fakulta OU, Fráni Šrámka 3, 709 00, Ostrava Mariánské Hory, ČR, tel.: 00420553462 615, e-mail: ladislav.rudolf@osu.cz 